\title{
Storage of Amaranth Seeds: Reflex in Physiologic Potential
}

\author{
Andréa Bicca Noguez Martins ${ }^{1}$, Ivan Ricardo Carvalho ${ }^{1}$, Caroline Jácome Costa $^{2}$, Fernanda Sedrez Marques ${ }^{1}$, \\ Robson Luiz Legório Marques ${ }^{1}$, Fernanda da Motta Xavier ${ }^{1}$, Jerffeson Araujo Cavalcante ${ }^{1}$, \\ Rafael de Oliveira Vergara ${ }^{1}$, Sheila Bigolin Teixeira ${ }^{1}$, Alberto Bohn ${ }^{1}$, Lilian Vanussa Madruga de Tunnes ${ }^{1}$, \\ Vinicius Kiesow Macedo ${ }^{1}$, Bruna Barreto dos Reis ${ }^{1}$, Anna dos Santos Sunne ${ }^{1} \&$ Dario Munt de Moraes ${ }^{1}$ \\ ${ }^{1}$ Departamento de Fitotecnia, Faculdade de Agronomia Eliseu Maciel, Universidade Federal de Pelotas, Pelotas, \\ Rio Grande do Sul, Brazil \\ ${ }^{2}$ EMBRAPA Clima Temperado, Pelotas, Rio Grande do Sul, Brazil \\ Correspondence: Ivan Ricardo Carvalho, Departamento de Fitotecnia, Faculdade de Agronomia Eliseu Maciel, \\ Universidade Federal de Pelotas, Pelotas, Rio Grande do Sul, Brazil. E-mail: carvalho.irc@gmail.com
}

Received: January 25, 2019

Accepted: March 14, 2019 Online Published: July 31, 2019

doi:10.5539/jas.v11n12p79

URL: https://doi.org/10.5539/jas.v11n12p79

\begin{abstract}
The aimed to evaluate the effect of packages and different environment conditions in the maintenance of physiologic quality of Amaranthus cruentus seeds in the period of 300 days. The seeds used were from the cultivar BRS Alegria indicated for use in Brazilian winter. The experimental design completely randomized in factorial scheme (storage environment $\times$ package type $\times$ storage period) with four replicates. The amaranth seeds storage in plastic packages, in refrigerator and cold chamber, resulted in better germination maintenance ability. The conditioning in PET package, in natural and cold chamber environments promoted better results in relation to germination. The storage period did not present significant effect for the seeds stored in refrigerator and PET, although, for paper package there was reduction. The amaranth seeds, cv. BRS Alegria, can be stored in cold chamber for until 300 days, conditioned in PET, without reduction of its physiologic potential.
\end{abstract}

Keywords: Amaranthus cruentus L., seed production, pseudocereals

\section{Introduction}

The amaranth (Amaranthus cruentus L.) has its origin in Southern and Central America, besides being little know or disclosed in the Brazilian agriculture, it is economically important in other parts of the world (Spehar et al., 2003). Its seeds present an oil content around 5.6 to 10.6\% (Marcílio et al., 2005). Furthermore, the fiber content found in this species is $25 \%$ superior to wheat and maize Moreover, the species contains substances that perform a range of biologic activities in human diet, such as inhibitors of protease, antimicrobial activity, peptide, lecithin and antioxidant compounds. The amaranth presents high contents of protein in leaves and grains, consisting of elevated concentrations of calcium, magnesium, phosphorus, zinc and iron in foliar tissues, in comparison to other cereals, as maize, rice and wheat (Costa et al., 2008).

The seed stands out as an input of high importance in the context of yield, and in order to be considered of high quality it must present adequate physiologic, physic, sanitary and genetic characteristics (França-Netoet al., 2010). These characteristics are fundamental for the plants to express all its potential and elevate the culture final yield (Szareskiet al., 2018).

Large adaptation and commercial production of amaranth in Brazil depend, however, in studies related to the seeds quality. Since one of the main issues that limit the amaranth production in subtropical and tropical regions around the globe is the seed quality.

The seeds storage for the next crop season is a common practice among farmers. The process of seeds deterioration might be reduced if applied a correct storage process, which maintains the seeds viability (Lins et al., 2014). In the storage environment, the relative air humidity, followed by the temperature, are the main factors that affect the seeds physiologic quality, directly interfering in its metabolic processes (Sravanthi et al., 2013).

The relative air moisture directly affects the water content in seeds and, when combined with elevated temperatures, intensifies the seeds respiration (Marcos Filho, 2005). The consequences of an elevated respiration are humidity and heating of seeds mass, aggravated by the microorganisms and insects (Baudet \& Villela, 2006). 
The seeds spend internal reserves, causing mass loss and drastic decrease in germination (Carvalho, Nakagawa, 2012).

Seed quality is basically determined by their physiological potential, which gathers information on viability and vigor of a seed lot, with the potential term translated as virtuality or set of skills to perform tasks and produce results (Marcos Filho, 2005).

When speaking of maintaining the physiologic quality during the storage, the package is of fundamental importance. The package types used to store may directly affect the quality, avoiding or not the humidity exchange between the seeds and environment (Medeiros \& Zanon, 2000). The main function of seeds package is to lag its deterioration by reducing respiration (Tonin \& Perez, 2006).

In this manner, the modern conservation techniques allow only to prolong the utile life of the seeds during storage (Silva et al., 2015). According to the exposed and facing the importance of the study of amaranth seeds during storage, this study aimed to evaluate the effect of packages and different environment conditions in the maintenance of physiologic quality of Amaranthuscruentus seeds in the period of 300 days.

\section{Material and Methods}

The amaranth seeds were obtained in experiment carried out in Experimental Field of the Plant Science Department of the EliseuMaciel Agronomy College, from the Federal University of Pelotas, in the city of Capão do Leão (31 $46^{\prime} 3^{\prime \prime}$ Southern, longitude: 52 $26^{\prime} 55^{\prime \prime}$ and altitude of $30 \mathrm{~m}$ ) in the state of Rio Grande do Sul, Brazil, in the crop season of 2013. The region climate, according to Köppen and Geiger (1928), is Cfa type. The average temperature and rainfall were $18{ }^{\circ} \mathrm{C}$ and $1378 \mathrm{~mm}$, respectively. The soil is classified as albaqualf soil (Embrapa-Cnps, 2006).

The seeds used were from the cultivar BRS Alegria, of the EmbrapaProdutos de Mercado germplasm, indicated for use in Brazilian winter, with cycle of 110 days from the emergence to maturation. The seeds stayed stored in its respective packages in the Seeds Analysis Laboratory, of the Federal University of Pelotas, until the experiment realization.

The values of water content in seeds were not submitted to statistical analysis. For the data referent to seeds physiologic quality, it was adopted the experimental design completely randomized, with factorial scheme $3 \times 3$ $\times 6$ (storage environment $\times$ package type $\times$ storage period) with four replicates, were transformed in $\arcsin \sqrt{ }$, in order to homogenize the variance of experimental errors. The presented values in tables are referent to original data.

The experiment was conducted from January to September 2016, where, Factor A-types of packages: paper, plastic and polyethylene (PET); Factor B-storage environments: natural, non-controlled, cold chamber and refrigerator; Factor C-storage periods: 0, 60, 120, 240 and 300 days. It was used four replicates, in subdivided plots, combining the factors type of package and storage environments in the plot and storage period in the subplot.

The packages were polyethylene plastic bags, kraft paper bag and transparent PET bottle. For the cold chamber conditions, the seeds were kept in temperature of $15^{\circ} \mathrm{C}\left( \pm 2{ }^{\circ} \mathrm{C}\right)$ and relative humidity $(\mathrm{RH})$ between 40 and $50 \%$. The refrigerator condition was temperature of $8{ }^{\circ} \mathrm{C}$, while for natural environment condition, the seeds were maintained in room with environment temperature, without solar radiation. The values of average temperature and relative air humidity were obtained within the meteorological station of Embrapa Clima Temperado (Figure $1)$. 

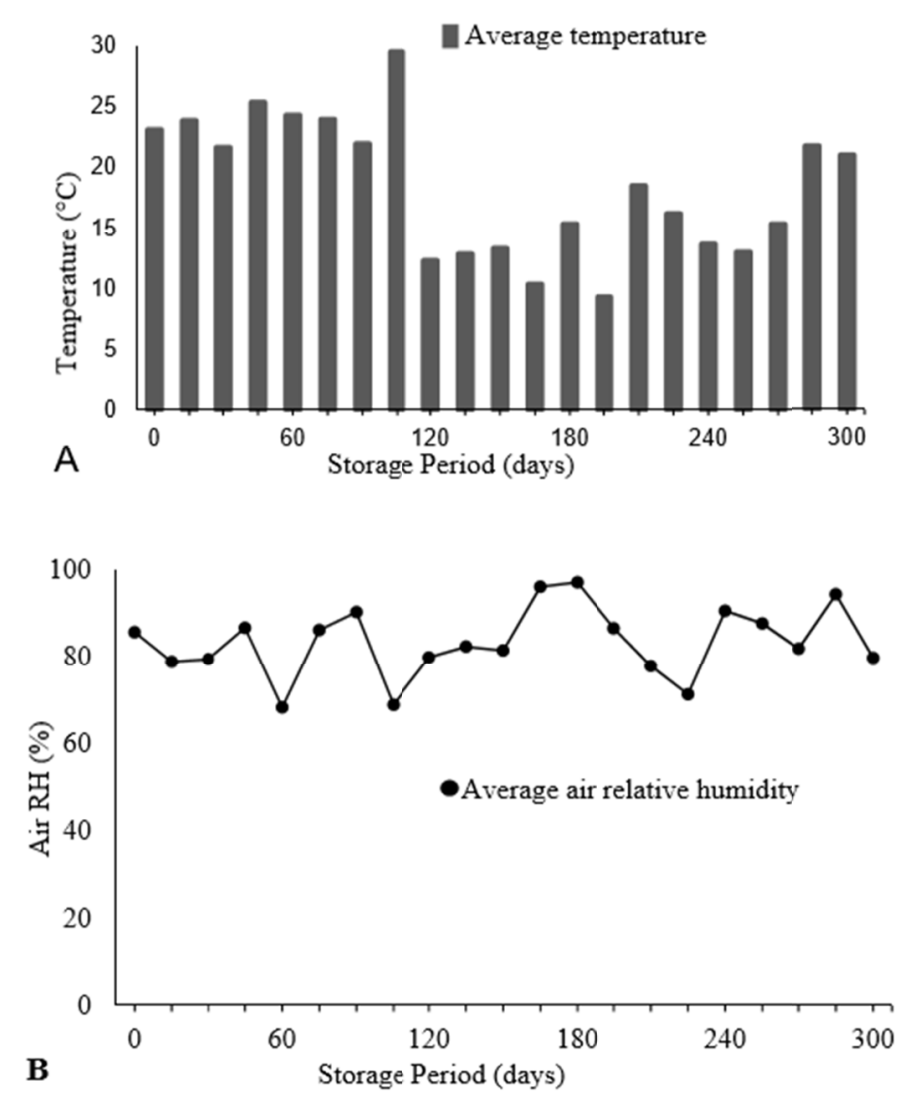

Figura 1. Average temperature and relative air humidity, during the storage period of amaranth seeds in the environment natural condition. Pelotas, RS, 2016/2017

The evaluation realized to characterize the physiologic quality of seeds were humidity degree, germination, first germination counting and seedling emergence in plant bed. The determination of the humidity degree was realized by the kiln method, at $105 \pm 3{ }^{\circ} \mathrm{C}$, for 24 hours (Brasil, 2009). It was realized in the beginning of the experiment implementation and at the end of every storage period.

The germination analysis was realized with four replicates of 50 seeds, employing two sheets of blotting paper, wetted with distilled water with 2.5 times the mass of dry paper. The germinator temperature in which the seeds were disposed was $20-30{ }^{\circ} \mathrm{C}$ alternated, and evaluations realized 14 days after the first seeding (DAS), being the results expressed in percentage of normal seedlings (Brasil, 2009).

The first germination counting was carried out with the germination test, five days after the test implementation, and results expressed in percentage of normal seedlings (Brasil, 2009).

For the emergence in plant beds, 200 seeds were sowed in beds of $5 \times 1 \mathrm{~m}$ distributed in four lines of 50 seeds each. After sowing, the soil humidity was kept in field capacity. The evaluation was realized in single counting, at 21 days after sowing, being results expressed in percentage of emerged seeds (Nakagawa, 1999).

The data were analyzed to normality and homoscedasticity and, if not meet the conditions, were realized data transformations and, afterwards, submitted to variance analysis $(p<0.05)$, expressed in percentage and transformed to $\arcsin \sqrt{ }$, in order to homogenize the residue variances. In this manner, when significant by $\mathrm{F}$ test, the means of seeds condition and storage condition were compared by Tukey test, and storage period submitted to polynomial regression analysis, all at $5 \%$ of probability.

\section{Results and Discussion}

The values of humidity degree of amaranth seeds stored in different environments, type of package and storage period (Table 1) revealed that lower gains of humidity were obtained in the cold chamber environment $(9.9 \%)$, followed by natural environment $(10.9 \%)$ and refrigerator $(10.2 \%)$. In the last one, the seeds presented higher humidity gains within storing, mainly because of seasonal variation that occurs within the year. In environments with constant humidity variation, the seeds are exposed to variations in water content (Souza et al., 2016). Even 
though, in relation to rice (Oryza sativa L.) seeds storage in the same environment, it was observed an increase in humidity degree when in cold chamber (Regalo \& Brena, 2006).

The seeds stored in permeable packages (paper) suffered higher influence of atmosphere conditions form the storing local than the ones stored in impermeable packages (PET and plastic). This fact was expected, since this type of package does not offers resistance to vapor exchanges of seed water with the environment, differing from the impermeable, which does not allow exchanges and present higher resistance than the permeable (Table 1). In cambre seeds, the PET package presented higher WVPI (water vapor permeability index), fact that explains the larger oscillation in water content values of seeds within the storage in this kind of package (Bessa et al., 2015).

The relative humidity and temperature conditions during the storing, in which the products will reach its specific hygroscopic equilibrium, will determine the maintaining of its physiologic quality, for a larger or shorter period (Borges et al., 2009). Because of it, it is important to store seeds in packages capable of inhibit gas exchange between the seed and the external environment, causing it to reach hygroscopic equilibrium and avoiding possible seeds tissues detrition due to constant water loss or gain and variation in the respiration ratio.

It is important to highlight that the knowledge of humidity degree of seeds is essential to determine adequate conditions to storage, which depends on the relative humidity that is influenced by environment temperature and package type (Warhm, 1996).

Table 1. Humidity degree (\%) from amaranth seeds cv. BRS Alegria, stored in different environments, types of packages and storing periods. UFPel/RS, 2016/2017

\begin{tabular}{|c|c|c|c|c|c|c|c|c|c|}
\hline \multirow{4}{*}{ Storingperiods (days) } & \multicolumn{9}{|c|}{ Storingenvironment } \\
\hline & \multicolumn{3}{|c|}{ Natural } & \multirow{2}{*}{\multicolumn{3}{|c|}{$\begin{array}{c}\text { ColdChamber } \\
\text { Typeofpackage }\end{array}$}} & \multicolumn{3}{|c|}{ Refrigerator } \\
\hline & & & & & & & & & \\
\hline & Paper & Plastic Bag & PET & Paper & Plastic Bag & PET & Paper & Plastic Bag & PET \\
\hline 0 & 10.3 & 10.3 & 10.3 & 10.3 & 10.3 & 10.3 & 10.3 & 10.3 & 10.3 \\
\hline 60 & 10.7 & 10.6 & 10.6 & 9.9 & 9.7 & 10.5 & 11.0 & 10.6 & 10.4 \\
\hline 120 & 10.9 & 10.7 & 10.5 & 9.4 & 10.3 & 10.6 & 9.7 & 10.4 & 10.5 \\
\hline 180 & 11.7 & 10.7 & 10.7 & 9.9 & 10.0 & 10.2 & 9.0 & 10.8 & 10.6 \\
\hline 240 & 12.8 & 10.6 & 10.7 & 9.8 & 9.5 & 9.8 & 9.0 & 10.5 & 10.5 \\
\hline 300 & 13.7 & 10.6 & 10.5 & 9.9 & 9.8 & 10.2 & 9.1 & 9.7 & 10.4 \\
\hline \multirow[t]{2}{*}{ Mean (\%) } & 11.7 & 10.6 & 10.5 & 9.8 & 9.9 & 10.2 & 9.7 & 10.4 & 10.4 \\
\hline & & 10.9 & & & 9.9 & & & 10.2 & \\
\hline
\end{tabular}

According to the variance analysis for the variables first germination counting, germination and seedlings emergence in plant beds, obtained from amaranth seeds cv. BRS Alegria, submitted to different storing periods, conditioned in diverse packages and storing conditions (Table 2). It was possible to observe that there was interaction between the studied factors for the variables germination and field germination. Although, for the variable first germination counting, there was significant interaction for the combination of the factors storage period $\times$ packages and storing conditions $\times$ packages. However, for being isolated factors, it was instated significance for all studied variables. 
Table 2. Summary of variance analysis for the variables, germination $(\mathrm{G})$, first germination counting (PCG) and Seedlings emergence in plant beds (EC), obtained from amaranth seeds cv. BRS Alegria, submitted to different storing periods (PA), conditioned in different packages (EMB) and storing conditions (CA). UFPel/RS, 2016/2017

\begin{tabular}{lllll}
\hline Sourceofvariation & GL & G & PCG & EC \\
\cline { 2 - 5 } Replicate & 3 & & & \\
PA & 5 & $*$ & $*$ & $*$ \\
Residue A & 18 & - & - & - \\
PA $\times$ EMB & 2 & $*$ & $*$ & $*$ \\
Residue B & 10 & $*$ & $*$ & $*$ \\
CA & 36 & - & - & - \\
CA $\times$ PA & 2 & $*$ & $*$ & $*$ \\
CA $\times$ EMB & 10 & $*$ & ns & $*$ \\
CA $\times$ PA $\times$ EMB & 4 & $*$ & $*$ & $*$ \\
Residue C & 20 & $*$ & ns & $*$ \\
\hline
\end{tabular}

Note. $*$ or $\mathrm{ns}=$ significant or non-significant at $5 \%$ of probability by $\mathrm{F}$ test.

For the germination, comparing the package types in each environment and storing period, it was observed that, the storage in natural environment, the percentage of normal seedlings was inferior to those conditioned in PET, independent of the storing period (Table 3). Although, when considering the storage environment, independent of the period and package, it was verified that seeds stored in cold chamber had larger values of viability, except at 180 days, for the plastic and paper packages, being these considered impermeable.

In the comparison of storage environments, when stored in plastic packages, it was verified that, in general, the seeds storage in refrigerator and cold chamber proportionated better maintenance of amaranth seeds germination (Table 3). However, the storing in PET packages, there was larger percentage of normal seedlings in natural environments and cold chamber. When stored in paper packages, it was verified difference in seeds germination only in the evaluations realized at 240 and 300 storing days, where the storage in cold chamber proportionated preservation of the normal seedlings percentage.

Studies executed to evaluate the effects of different storage environments in the germination of amaranth seeds observed that the amaranth seeds can be stored for 16 months in aluminum cans and keep its viability, without harming the germination percentage (Adam et al., 2017). 
Table 3. Germination (\%) from amaranth seeds, cv. BRS Alegria, submitted to different environments, types of packages and storing periods. UFPel/RS, 2016/2017

\begin{tabular}{|c|c|c|c|c|c|}
\hline \multicolumn{6}{|l|}{ Germination (\%) } \\
\hline \multirow{2}{*}{ Período (days) } & \multirow{2}{*}{ Environment } & \multicolumn{3}{|c|}{ Package } & \multirow{2}{*}{ - Mear } \\
\hline & & Plastic & PET & Paper & \\
\hline \multirow{4}{*}{0} & Natural & 91 a A & 91 a A & 91 a A & 91 \\
\hline & Refrigerator & 91 a A & 91 a A & 91 a A & 91 \\
\hline & ColdChamber & 91 a A & 91 a A & 91 a A & 91 \\
\hline & Mean & 91 & 91 & 91 & \\
\hline \multirow{4}{*}{60} & Natural & 82 c B & 90 a $\mathrm{A}$ & $86 \mathrm{~b} \mathrm{~A}$ & 86 \\
\hline & Refrigerator & $86 \mathrm{~b} \mathrm{~A}$ & 88 a B & $87 \mathrm{ab} A$ & 87 \\
\hline & ColdChamber & 87 a A & 89 a $\mathrm{AB}$ & 88 a A & 88 \\
\hline & Mean & 85 & 89 & 87 & \\
\hline \multirow{4}{*}{120} & Natural & $83 \mathrm{c} \mathrm{B}$ & 90 a A & $86 \mathrm{~b} \mathrm{~A}$ & 86 \\
\hline & Refrigerator & $86 \mathrm{~b} \mathrm{~A}$ & 88 a B & $87 \mathrm{ab} A$ & 87 \\
\hline & ColdChamber & 87 a A & 88 a B & 88 a A & 87 \\
\hline & Mean & 85 & 88 & 87 & \\
\hline \multirow{4}{*}{180} & Natural & $81 \mathrm{~b} \mathrm{~B}$ & 88 a B & 88 a A & 85 \\
\hline & Refrigerator & $86 \mathrm{~b} \mathrm{~A}$ & 88 a B & $87 \mathrm{ab} A$ & 87 \\
\hline & ColdChamber & $83 \mathrm{c} \mathrm{B}$ & 90 a A & 86 b A & 86 \\
\hline & Mean & $83^{-1}$ & 88 & 87 & \\
\hline \multirow{4}{*}{240} & Natural & 82 c B & 89 a A & $85 \mathrm{~b} \mathrm{~B}$ & 85 \\
\hline & Refrigerator & 85 a A & 87 a B & 85 a B & 85 \\
\hline & ColdChamber & 87 a A & 88 a $\mathrm{AB}$ & 88 a A & 87 \\
\hline & Mean & 84 & 88 & 86 & \\
\hline \multirow{4}{*}{300} & Natural & $81 \mathrm{c} \mathrm{C}$ & 88 a A & $84 \mathrm{~b} \mathrm{~B}$ & 87 \\
\hline & Refrigerator & 84 a B & 85 a B & $80 \mathrm{~b} \mathrm{C}$ & 83 \\
\hline & ColdChamber & 86 a A & 87 a A & 86 a A & 86 \\
\hline & Mean & $83^{-1}$ & 86 & $83^{-1}$ & \\
\hline
\end{tabular}

Note. * Means followed by same lowercase letter in line, in each variable, and uppercase in column, in each storing period, do not differ themselves by Tukey test $(\mathrm{p} \leq 0.05)$.

Analyzing the germination behavior within the storage (Figure 2), it was observed that in the natural environment, the storage in plastic package presented quadratic tendency, with fast germination reduction until 215 days of storage, and later increase until the end of storage. In PET storage in natural environment, it was observed low linear reduction of approximately 0.66 germination percentage points for every 60 days of storage. While in the paper package, it was observed cubic behavior tendency for germination, with minimum viability point at 128 days and maximum point of germination at 252 days.

In the refrigerator storage, for all three packages types, it was observed cubic behavior for germination, with reduction of approximately 120,127 and 106 days, respectively, followed by stabilization and decline of germination at 279, 166 and 180 days, respectively. Stands out the larger germination reduction for the seeds stored in paper, when compared to the reduction observed for other types of packages, presenting 300 days of storage, germination percentage of 6 and 5 percentage points less than the seeds stored in PET and plastic, respectively (Figure 2). The same behavior was identified in sunflower and pea, which presented reduction in germination when stored in Kraft paper compared to semi-permeable and impermeable packages (Lins et al., 2014; Lisboa et al., 2014).

For the storage in cold chamber, there was reduction of germination with quadratic tendency for seeds stored in plastic packages, with reduction of germination until 295 days. However, for seeds stored in PET and paper packages, it was verified cubic tendency, with initial reduction of germination until the periods of 107 and 132 days, respectively. Later, it was observed stabilization and new reduction of germination, at 257 and 242 days of storing for PET and paper packages, respectively (Figure 2).

The non-controlled environment occasioned larger reduction in the physiologic potential of soybean seeds, in comparison to cold chamber, through the results of vigor and germination (FORTI et al., 2010). However, it may 
occur an intensification process of deterioration with the extension of the storing period, even in refrigerated environment (Cunha et al., 2009).

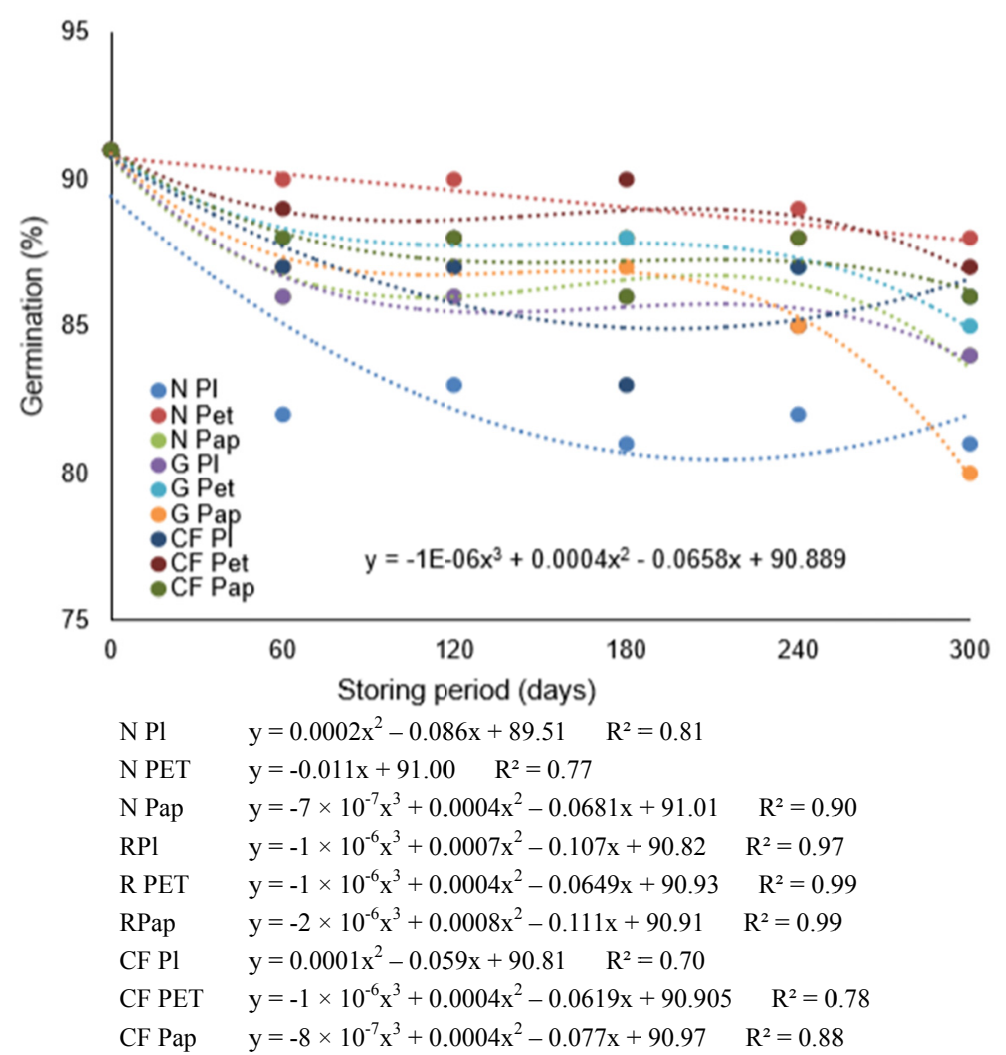

Figure 2. Germination (\%) of amaranth seeds, cv. BRS Alegria, submitted to storing periods, in different storing periods (PA), in different environments (N: Natural; G: Refrigerator; CF: Cold Chamber) e types of packages (Pl: Plastic; PET; Pap: Paper).UFPel/RS, 2016/2017

Comparing the types of packages used in each storing period, for the variable first germination counting, it was observed that the storage in PET was superior to the storage in plastic and paper, in all evaluation periods, being that, at 180 and 240 days, the paper storing presented lower percentage of normal seedlings (Table 4). This behavior may be reflex of the thickness of the material used, which allows lower protection to the seeds during storage. Baudet and Villela (2012) stated that packages with thickness lower than $0.075 \mathrm{~mm}$ are capable of maintain seeds inert of gas exchanges with the environment, as it is the case of paper package in this study. The superior performance verified in PET package can be explained by the stability of the humidity degree of seeds during storing periods, in comparison to paper and plastic packages (Table 1).

Table 4. First germination counting (PCG) from amaranth seeds cv. BRS Alegria, submitted to different types of packages and storing periods. UFPel/RS, 2016/2017

\begin{tabular}{|c|c|c|c|}
\hline \multirow{2}{*}{ Period (days)/Package } & \multicolumn{3}{|c|}{ PCG (\%) } \\
\hline & Plastic & PET & Paper \\
\hline 0 & $68 \mathrm{a}$ & $68 \mathrm{a}$ & $68 \mathrm{a}$ \\
\hline 60 & $66 \mathrm{~b}$ & $68 \mathrm{a}$ & $65 \mathrm{~b}$ \\
\hline 120 & $66 \mathrm{~b}$ & $68 \mathrm{a}$ & $65 \mathrm{~b}$ \\
\hline 180 & $65 \mathrm{~b}$ & $67 \mathrm{a}$ & $64 \mathrm{c}$ \\
\hline 240 & $64 \mathrm{~b}$ & $67 \mathrm{a}$ & $63 \mathrm{c}$ \\
\hline 300 & $63 \mathrm{~b}$ & $65 \mathrm{a}$ & $61 \mathrm{~b}$ \\
\hline C.V. $(\%)$ & 2.33 & & \\
\hline
\end{tabular}

Note. *Means followed by same lowercase letter in line do not differ themselves by Tukey test $(\mathrm{p}<0.05)$. 
The first germination counting test can be considered a vigor indicate, since the results revealed that, within storage, there was a quadratic tendency for seeds stored in PET, with maintenance of normal seedlings percentage until approximately 180 days of storage and low reduction after this period (Figure 3).

In relation to the plastic and paper packages, both presented linear decrease of $0.9 \%$ and $1.2 \%$, respectively, of normal seedlings for every 60 days of storage. Still in the end of the period, at 300 days, the first germination counting of the seeds stored in plastic was $6.7 \%$ lower, in comparison to the zero period, while, for the paper package, the reduction was $8.9 \%$.

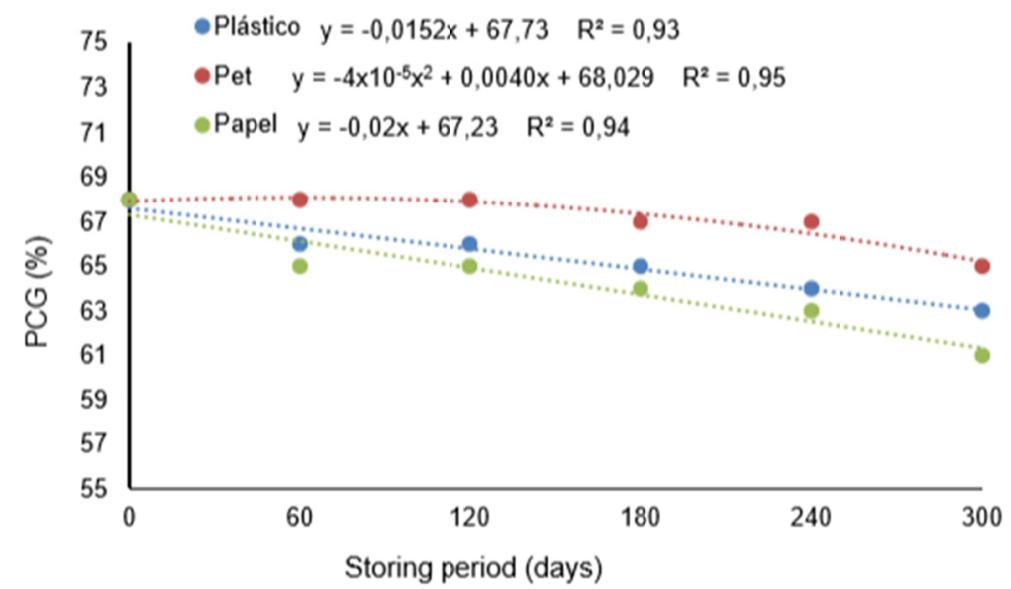

Figure 3. First germination counting (PCG) from amaranth seeds cv. BRS Alegria, submitted to different types of packages (Pl: Plastic; PET; Pap: Paper) and storing periods (PA) .UFPel/RS, 2016/2017

When comparing the storage condition and package type, for the first germination counting in the natural environment, the storage in PET and plastic did not differ to the percentage of normal seedlings, although, the seeds stored in PET presented results superior to the seeds stored in paper packages (Table 5). For the storing in refrigerator and cold chamber, the PET type package was superior to the rest. In relation to the environment, there was difference only to storing in paper packaging, where the refrigerator proportioned decrease in percentage of normal seedlings (Table 5). Lima et al. (2014), evaluating the availability of sesame seeds stored in many environments and packages, observed that seeds kept viability for at least 12 months when stored in refrigerator, independent of the package. Thus, the increase in air relative humidity can provoke increase of the deterioration due to elevation of respiration ratio, reserve consumption and then, reduction of seeds physiologic quality (Carvalho \& Nakagawa, 2012).

Table 5. First germination counting (PCG) from amaranth seeds cv. BRS Alegria, submitted to storage in different environments and types of packages. UFPel/RS, 2016/2017

\begin{tabular}{llll}
\hline \multirow{2}{*}{ Environment/Package } & \multicolumn{2}{c}{ PCG (\%) } \\
\cline { 2 - 4 } & Plastic & PET & Paper \\
\hline Natural & $65 \mathrm{ab} \mathrm{A}$ & $66 \mathrm{a} \mathrm{A}$ & $64 \mathrm{~b} \mathrm{~A}$ \\
Refrigerator & $66 \mathrm{~b} \mathrm{~A}$ & $68 \mathrm{a} \mathrm{A}$ & $62 \mathrm{c} \mathrm{B}$ \\
ColdChamber & $66 \mathrm{~b} \mathrm{~A}$ & $68 \mathrm{a} \mathrm{A}$ & $65 \mathrm{~b} \mathrm{~A}$ \\
\hline C.V. $(\%)$ & 3.16 & & \\
\hline
\end{tabular}

Note. *Means followed by same lowercase letter in line do not differ themselves by Tukey test $(\mathrm{p}<0.05)$.

In the evaluation of emergence of seedlings in plant beds and comparing types of packages in each environment and storing period, it was verified that the seeds maintained in natural environment did not present difference in the percentage of emerged seedlings, independentof the package used. The exception is to seeds evaluated at 300 days, where the storing in paper provided reduced seedlings emergence, besides not being statistically different to the plastic package (Table 6). 
In the refrigerator storage, the seeds kept in PET packages presented larger percentage of emerged seedlings. However, the seeds that were kept in cold chamber and PET and paper packages presented higher percentage of emerged seedlings, except in 240 and 300 days, where only PET proportioned the maintenance of vigor during the storage period (Table 6).

The comparison between storage environments, for seeds kept in plastic packages it was observed difference at 60, 120 and 180 storing days, where the seeds kept in refrigerator has reduction of seedlings emergence, while at 240 and 300 days, the seeds in cold chamber presented lower vigor expression (Table 6). In seeds stored in PET, in general, there was no difference in relation to environment, however, at 240 and 300 days of storage, the seeds kept in natural environment showed lower seedlings emergence. Although, the seeds that were kept in paper packages had, in general, the maintenance of vigor in natural and cold chamber environments.

Table 6. Seedlings emergence in plant beds (EC) from amaranth seeds, cv. BRS Alegria, maintained in different environments, types of packages and storing periods. UFPel/RS, 2016/2017

\begin{tabular}{|c|c|c|c|c|c|}
\hline \multicolumn{6}{|c|}{ Seedlings Emergence (\%) } \\
\hline \multirow{2}{*}{ Período (days) } & \multirow{2}{*}{ Environment } & \multicolumn{3}{|c|}{ Package } & \multirow{2}{*}{ Mean } \\
\hline & & Plastic & PET & Paper & \\
\hline \multirow{4}{*}{0} & Natural & 88 a A & 88 a A & 88 a A & 88 \\
\hline & Refrigerator & 88 a A & 88 a A & 88 a A & 88 \\
\hline & ColdChamber & 88 a A & 88 a A & 88 a A & 88 \\
\hline & Mean & 88 & 88 & 88 & \\
\hline \multirow{4}{*}{60} & Natural & 87 a $\mathrm{A}$ & 88 a A & 87 a A & 87 \\
\hline & Refrigerator & $84 \mathrm{~b} \mathrm{~B}$ & 88 a A & $81 \mathrm{c} \mathrm{B}$ & 84 \\
\hline & ColdChamber & $86 \mathrm{~b} \mathrm{~A}$ & 89 a A & $87 \mathrm{~b} \mathrm{~A}$ & 87 \\
\hline & Mean & 85 & 88 & 85 & \\
\hline \multirow{4}{*}{120} & Natural & 87 a A & 86 a A & 87 a $\mathrm{A}$ & 86 \\
\hline & Refrigerator & $83 \mathrm{~b} \mathrm{~B}$ & 88 a A & $81 \mathrm{c} \mathrm{B}$ & 84 \\
\hline & ColdChamber & $86 \mathrm{~b} \mathrm{~A}$ & 88 a A & $87 \mathrm{ab} A$ & 87 \\
\hline & Mean & 85 & 87 & 85 & \\
\hline \multirow{4}{*}{180} & Natural & 86 a A & 86 a $\mathrm{AB}$ & 86 a $\mathrm{A}$ & 86 \\
\hline & Refrigerator & $83 \mathrm{~b} \mathrm{~B}$ & 87 a A & $81 \mathrm{c} \mathrm{B}$ & 83 \\
\hline & ColdChamber & $86 \mathrm{~b} \mathrm{~A}$ & 89 a A & $88 \mathrm{ab} A$ & 87 \\
\hline & Mean & 85 & 87 & 85 & \\
\hline \multirow{4}{*}{240} & Natural & 85 a A & 85 a B & 85 a A & 85 \\
\hline & Refrigerator & $83 \mathrm{~b} \mathrm{AB}$ & 87 a AB & $80 \mathrm{c} \mathrm{B}$ & 83 \\
\hline & ColdChamber & $81 \mathrm{c} \mathrm{B}$ & 88 a A & $86 \mathrm{~b} \mathrm{~A}$ & 85 \\
\hline & Mean & 83 & 86 & 83 & \\
\hline \multirow{4}{*}{300} & Natural & $84 \mathrm{ab} \mathrm{A}$ & 85 a B & $82 \mathrm{~b} \mathrm{~B}$ & 83 \\
\hline & Refrigerator & $82 \mathrm{~b} \mathrm{AB}$ & 86 a AB & $79 \mathrm{c} \mathrm{C}$ & 82 \\
\hline & ColdChamber & $81 \mathrm{c} \mathrm{B}$ & 87 a A & $85 \mathrm{~b} \mathrm{~A}$ & 84 \\
\hline & Mean & $82^{-1}$ & 86 & 82 & \\
\hline C.V. (\%) & & 2.04 & & & \\
\hline
\end{tabular}

Note. *Means followed by same lowercase letter in line, in each variable, and uppercase in column, in each storing period, do not differ themselves by Tukey test $(\mathrm{p} \leq 0.05)$.

The behavior of seedlings emergence obtained in seeds in natural environment presented tendency of linear reduction of 8.2, 0.76 and 1.1 percentage points for every 60 storing days for plastic, PET and paper packages, respectively, occurring reduction of vigor, even in seeds kept in impermeable packages (Figure 4). The increase in water content in seeds kept in impermeable packages occurs due to the higher respiratory frequency of seeds that proportioned higher waterrelease and increase of relative humidity inside the package, thus, the seeds seek to adjust to the new air relative humidity and, consequently, acquire water content superior to the initial level (Carvalho \& Nakagawa, 2012).

For the condition of refrigerator storing, the seeds placed in plastic packages has a cubic tendency, with reduction of emerged seedlings percentage of approximately 124 days, followed by stabilization until the end of 
the storage period (Figure 4). The storage period did not present significant effect for seeds placed in refrigerator and in PET package, in relation to seedlings emergence (Figure 4). Although, for paper package, there was reduction of seedlings emergence with cubic tendency of 110 days, and new reduction after 250 storing days. For cold chamber storing, it was verified linear decrease of seedlings emergence, of 1.5 and 0.6 percentage points for seeds kept in plastic and paper, respectively. However, for seed that were stored in PET packages, it was not observed significant effect of the storing period on the seedlings emergence (Figure 4).

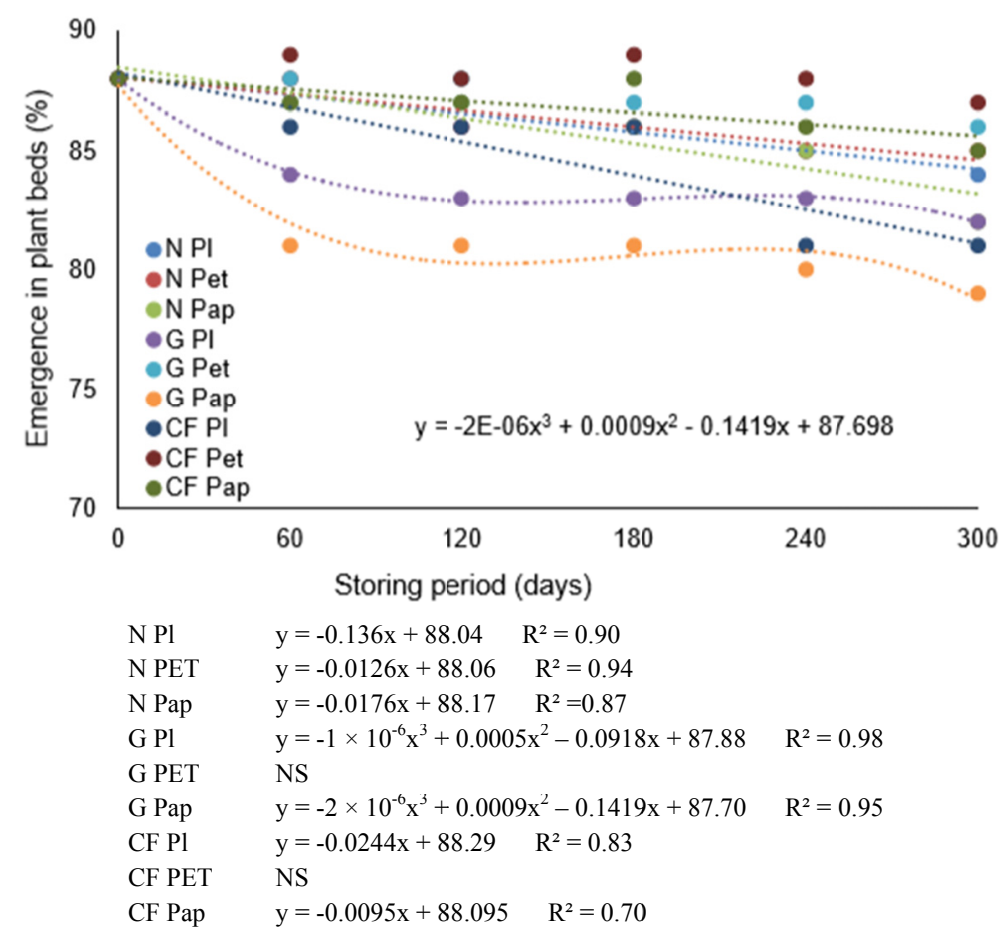

Figure 4. Seedlings emergence in palnt beds (EC) a partirfrom amaranth seeds cv. BRS Alegria, submitted to different storing periods (PA), in different conditions (N: Natural; G: Refrigerator; CF: Cold Chamber) and types of packages (Pl: Plastic; PET; Pap: Paper). UFPel/RS, 2016/2017

\section{Conclusions}

The amaranth seeds storage in plastic packages, in refrigerator and cold chamber, resulted in better germination maintenance ability. The conditioning in PET package, in natural and cold chamber environments promoted better results in relation to germination.

The amaranth seeds, cv. BRS Alegria, can be stored in cold chamber for until 300 days, conditioned in PET, without reduction of its physiologic potential.

\section{References}

Adam, O., Anthony, O., Olabisi, O., Oluwaseyi, A., \& Mary, A. A. (2017). The effect of storage environments and duration on seed germination of amaranth (Amaranthus cruentus). Journalof Experimental Agriculture International, 19(4), 1-7. https://doi.org/10.9734/JEAI/2017/38439

Baudet, L., \& Villela, F. A. (2012). Armazenamento de Semente. In S. T. Peske, F. A. Villela, \& G. E. Meneghello (Eds.), Sementes: Fundamentoscientíficos e tecnológicos (3rd ed., pp. 482-527). Pelotas: UFPEL

Baudet, L., \& Villela, F. A. (2006). Armazenamento de Sementes. In S. T. Peske, O. A. Lucca Filho, \& A. C. S. A. Barros (Eds.), Sementes: Fundamentoscientificos e Tecnológicos (2nded.). Pelotas: Ed.Universitária.

Bessa, J. F. V., Donadon, J. R., Resende, O., Alves, R. M. V., Sales, J. F., \& Costa, L. M. (2015). Armazenamento do crambe em diferentes embalagens e ambientes: Parte I-Qualidade fisiológica. Revista Brasileira de Engenharia Agricola e Ambiental, 19(3), 224-230. https://doi.org/10.1590/1807-1929/agriambi. v19n3p224-230 
Borges, S., Borges, E. E. L., Corrêa, P. C., \& Brune, A. (2009). Equilíbrio higroscópico e viabilidade de sementes de angico-vermelho (Anadenanthera peregrina (L.) Speng) em diferentes condições ambientais de armazenamento. ScientiaForestalis, 37, 475-481.

Brasil. (2009). Ministério da Agricultura, Pecuária e Abastecimento. Regras para Análise de Sementes. Secretaria de DefesaAgropecuária. Brasília: MAPA/ACS.

Carvalho, N. M., \& Nakagawa, J. (2012). Sementes: ciencia, tecnologia e produção (5th ed., p. 590). FUNEP.

Cunha, J. P. A. R., Oliveira, P., Santos, C. M., \& Mion, R. L. (2009). Qualidade das sementes de soja após a colheita com dois tipos de colhedora e dois períodos de armazenamento. Ciência Rural, 39(5), 1420-1425. https://doi.org/10.1590/S0103-84782009005000063

Embrapa. (2006). Centro Nacional de Pesquisa do Solo. Sistema brasileiro de classificação de solos (2nd ed., p. 306). Rio de Janeiro: Embrapa Solos.

França Neto, J. B., Krzyzanowski, F. C., \& Henning, A. A. (2010). A importância do uso de sementes de soja de alta qualidade. Informativo Abrates, 20(1-2), 37-38.

Köppen, W., \& Geiger, R. (1928). Klimate der Erde (p. 1928). Gotha: Verlagcondicionadas. Justus Perthes.

Lins, S. R. O., Carvalho, M. L. M., Cardoso, M. G., Miranda, D. H., \& Andrade, J. P. (2014). Physiological, enzymatic, and microstructural analyses of sunflower seeds during storage. Australian Journal, 8, 1038-1048.

Lisboa, C. F., Cunha, D. A., Teixeira, I. R., Devilla, I. A., \& Campos, A. J. (2014). Physiological deterioration of pigeon pea seeds during storage. AfricanJournalAgriculturalResearch, 9(48), 3473-3479.

Marcílio, R., Farfan Amaya, J., \& Spehar, C. R. (2005). Deveria o Brasil investir em novos grãos para a sua alimentação? A proposta do amaranto (Amaranthus sp.). Revista SegurançaAlimentar e Nutricional, 12, 47-56.

Marcos Filho, J. (2005). Relações água/semente. Fisiologia de sementes de plantas cultivadas (pp. 169-196). Piracicaba: FEALQ.

Medeiros, A. C., \& Zanon, A. (2000). Armazenamento de sementes de sapuva (Machaerium stipitatum). Boletim Pesquisa Florestal, 40, 57-66.

Nakagawa, J. (1999). Testes de vigor baseados no desempenho das plântulas. In F. C. Krzyzanowski, R. D. Vieira, \& J. B. França Neto (Eds.), Vigor de sementes: conceitos e testes (pp. 4-1-4-26). Londrina: ABRATES.

Regalo, M. J., \& Brena, S. R. (2006). The influence of drying methods and storage condition on the seed viability and longevity of Mestizo Hybrid Rice (Oryza sativa L.). Philippine Agricultural Science, 89(4), 309-318.

Silva, T. C., Alves, M. C. S., Teodoro, M. S., \& Lacerda, M. N. (2015). Avaliação e potencial fisiológico de sementes de Crotalariajuncea L. em três períodos diferentes de armazenamento. Enciclopédia Biosfera, Centro Cientifico Conhecer, 11(20), 40-52.

Souza, F. F. J., Devilla, I. A., Souza, R. T. G., \& Spehar, C. R. (2016). Physiological quality of quinoaseeds submitted to diferente storage conditions. African Journal of Agricultural Research, 11(15), 1299-1308. https://doi.org/10.5897/AJAR2016-10870

Spehar, C., Teixeira, D. L., Cabezas, W. A. R. L., \& Erasmo, E. A. L. (2003). Amaranth BRS Alegria: Alternative for diversificationofcropping systems. Pesquisa Agropecuária Brasileira, 38(5), 659-663. https://doi.org/ 10.1590/S0100-204X2003000500015

Sravanthi, B., Jayas, D. S., Alagusundaram, K., Chelladurai, V., \& White, N. D. G. (2013). Effect of storage conditions on redlentils. Journal of Stored Products Research, 53, 48-53. https://doi.org/10.1016/j.jspr. 2013.01.004

Szareski, V. J., Carvalho, I. R., Kehl, K., Levien, A. M., Nardino, M., Dellagostin, S. M., ... Aumonde, T. Z. (2018). Evaluation of the adaptability and stability of wheat genotypes using a phenotypic index of seed vigor. Pesquisa Agropecuária Brasileira, 53(6), 727-735. https://doi.org/10.1590/s0100-204x2018000 600009 
Tonin, G. A., \& Perez, S. C. J. G. A. (2006). Qualidade fisiológica de sementes de Ocotea porosa (Neeset Martius ex. Nees) após diferentes condições de armazenamento e semeadura. Revista Brasileira de Sementes, 28, 26-33. https://doi.org/10.1590/S0101-31222006000200004

Warhm, E. J. A. (1996). Comparison of packing materials for seed with particular reference to humid environments. Seed Science and Technology, 14(1), 191-211.

\section{Copyrights}

Copyright for this article is retained by the author(s), with first publication rights granted to the journal.

This is an open-access article distributed under the terms and conditions of the Creative Commons Attribution license (http://creativecommons.org/licenses/by/4.0/). 